\title{
Sindbad myth in the poem by Khalil Hawi
}

\author{
Nasser Ghasemi Rozveh ${ }^{1, a^{*}}$, Aida Danaye ${ }^{2, b}$ \\ ${ }^{1}$ Assistant Professor of Arabic Language and Literature, Tehran University, Iran \\ ${ }^{2}$ Master student of Arabic Language and Literature \\ Email address: ${ }^{a}$ naserghasemi@ut.ac.ir, ${ }^{b}$ aydadanaye@yahoo.com
}

\begin{abstract}
Keywords: myth, modern Arabic, Khalil Hawi
\end{abstract}
\begin{abstract}
Extensive use of mystery and myth as a means of expression is one of the most eminent artistic phenomena at new poetry experiences. The reflection of myths in poetry, is the most beautiful and artistic application of mythmaking. With reflection of myths, the mythological world became the parade ground for poet's imagination and creation and also for mythmaker writer, so it can link past and present, and by this way shows social and political deductions and perceptions for readers, and fulfills human art and cultural needs. Also, Arab current poets used of Arabic and even other old nation's myths, and expressed their thoughts and ideas by using these myths with respect to environment and circumstances. This paper aims to study the most dominant myths in Khalil Hawie`s poems, beside defining idiomatic and lexical of myth.
\end{abstract}

\section{INTRODUCTION}

The myth is the narrative or manifestation symbolic of gods, angels, supernatural creatures and in general world knowledge that a people use to their interpretation from being. Myth is a holy and right story that occurred at a time eternal and so symbolic, imaginary and illusionary tells how something occurred, is being, or will be lost and finally myth to the allegorical manner is the researcher of existence in other words, the myth is intuitive insight. Insight of the primitive societies and their interpretation of the world such the myth is manifested and although is located in the epic, myth and fairy tales row, but it is different from them. Myths are seems in such a rituals. The religious beliefs of primitive man begin from the myth, and later in more recent times, as religions are formed. Therefore, the myth is the religion and spiritual knowledge of primitive man and, knowledge that has more intuitive and symbolic aspects and is far from scientific laws of later periods. Mythological creatures are not natural, inspired by nature, but are supernatural such as god of wind, storm, sun, moon and so on. Qmars described in Avesta in mythological narratives is the first man, has a beast and robust body, and its appearance is not so common to the human body, while the epic characters are human really, but they are great humans as champions and heroes. The human characters in fairy tales and sometimes amazingly eerie imaginary animals can be seen. (Bahar, 1994: 196). The myth there was from the earliest days of human life, played social function until century ago, myths thought as the false and fake legend and was not important matter. From 19 th century, the myth was considered very serious and it is considered as daydreaming poetry or fiction, while early humans are believed that there is difference and border between myth and legend, they believed myth is fake and legend is a real story. The myth was the primitive man's interpretation of the world and nature and was considered more aspects of theoretical thought ancient man, whiles the traditions and rituals, were the its scientific aspects. The most important function of the myth is the discover and emerging paradigm of exemplary all meaningful rituals and activities of human, From nutrition to work and education, art and wisdom and other benefits of myth is taking advantage of its in literature and art. (Eliade, 1983: 14-15)

Myths function in Arabic poetry came back to the early years of the twentieth century, so that Gibran Khalil Gibran in his book (Tear and Smile) has used the myth of Adonis and Ashtar. Nasib Ariza in (fire garden) ode poems about the myth of Eram Zaat al-Emad. Akkad and Abushady and others in their odes also used the myth. However, the use of old and traditional characters from the poets, was visual and verbal, and had not dramatic and revelatory aspect and message. In addition, 
through these characters did not consider to modern human problems. However, the use of custom or legacy as an independent in terms of technical and dramatic style, dating back to the midtwentieth century. Therefore, great poets such as Adonis, Khalil Hawi, Badar Shaker Al-Sayyab, Abdul Wahhab al-Bayati, Amal Donqol and Salah Abdul Sabor did it. Political and social incentives in the Arabic lands are the main factors in desire of poets to the world of myth.

In this way, from the first years of the present decade, the size of mythology in modern Arabic literature widened and valuable translations has been published whether about the mythology of different nations or different perspectives on the analysis of mythology, such as analysis of psychoanalytical literary, artistic works and mythical criticism in Arabic literature.

The present thesis has been provided follow the need and enthusiasm of Arabic literature and poetry readers and interested in to explore the mythology, and understanding ancient myths. The author of this article has tried that with a relatively simple and comprehensive expression clarifies the dimensions of myth and investigates diverse views of mythology. As well as a variety of myths according to the modern Arab poetry of four poets myth maker (Adonis, Abdul Wahhab al-Bayati, Khalil Hawi, Khalil Matran) introduce to the readers of Arabic literature and poetry. It is hoped that searcher readers need, especially the artists and art lovers need of myth and mythology and recognition of myth Arabic literature provide somewhat.

Khalil Alhawi was born in Lebanon in 1925 and educated at the American University of Beirut in the field of philosophy and then went to Cambridge to study. Some of his poems are the result of his meditations in Cambridge. He received his Ph.D. in philosophy from Cambridge, is now a professor at the American University of Beirut, and taught the criticism, philosophy, and Arab literature. He has published three collections of poetry, including:

1. River ash, 1957, Beirut

2. Flute and wind, 1961, Beirut.

3. Byader Aljo, 1965, Beirut.

He has written a book by English about Gibran Khalil Gibran. (Salimi, 2011: 24)

-Myth in contemporary Arabic poetry:

Stable poetry is a result of dialectic (dependence on tradition and escape from tradition). As well as those of countless number of contemporary poets will be constant or to cope with the bumps or afford good dialectic. These poets are, whether in Western or in the West or Iran.

The most obvious effects of belonging to a tradition in contemporary Arab poetry, is the mythology and national reliquiae that mythological heritage among these for the reasons and causes more severe in the contemporary Arab literature became important. The most important influencing factor is imitation of Western poetry that myth has long been considered. Especially, after the realization of the great book of James Frazer i.e. golden bough by Jabra Ibrahim Jabra and through the translation of a chapter of the Freud Vyong psychological studies of the role of myth in the human subconscious, and other functions such as establish the link between man and nature and myth the seasons, create a clear vision of the evolution of human life and linking the activities of the conscious mind and subconscious dreams only of individual experience and collective experiences and dropping lyrical poetry of the time spent and insert other elements in it. (Sattari, $1995: 28)$

These and other factors led to the contemporary poets search the mythology reliquiae and seek their in all possible sources, it causes the diversity of myths in contemporary poetry: Babylonian (Tamuz), Egyptians (Osiris), Phoenician (Adonis), Greek (Sisyphus), Christian (Alazer), Islamic (Khezr) mythology and so on.

Mythology variation in the poem of the poet is dependent on the amount of mania and dedication to the myth, poetry like Al-Sayyab rivals from it, but the poet like Mahmoud Darwish has less attention to the myths, poets of Lebanon and Iraq seek in all sources, but Egyptian poets like some myths and unlike the others. (ibid: 36 )

There are several functions of the myth in contemporary Arabic poetry. However, the most important of them are: 
1- Expression of mental bewilderment and disorientation using myths like Olsys, Sinbad, and the Urfa

2- The expression of resurrection and rebirth with the Tamuz, Osiris, Phoenician myths

3- Expression of contemporary human suffering by Prometheus, Sisyphus, Jesus

For this reason is that contemporary human in the shadow of conflicts and multiple ethnic conflict make (historical myth); and use it as a stimulant the strengthening of collaboration and social unity of the nation.

In the contemporary period, even traditional poets have tried to use of myth making and recreating the mythical elements, close these elements to their era and awake with adjustments of the mythical with the aim of reflecting their era to help of past mythical. According to the most contemporary poets, the meaning has such importance to the use of myths; main opinion of poet is his expression and retains the same meaning. (Eliade, 1983: 16)

When we speak about contemporary poet with poetic heritage, we see a clear difference. Tending to new poem form, is really trying to get rid of the past. This form can be used to his freedom of action, experience and uniformity to reduce weight and rhyme, as well as the possibility of creating images and symbols, and provide encountering to the challenges of a new civilization. Some poets who have yet adopted this form, tend to use the old form, as well as traditional rhyme is dominated heavily on their poetry, so that sometimes poets to rhyme in verse involved by the anxiety, It is dominated by a large section of the poem, due to the lack of necessary verbs diversity. While some poets, each in turn trying to create a new poetic language, some of them used known and old images, and the common threads yet. (ibid: 16)

For example, still the same intensity and extent of his old satire is common and turns around the devious political people and poet obsequious. It all comes optional, with respect to it can be said that poetry cannot exceed the old poetic tradition. Maybe this is normal. Imagination the poet of his people is a factor that determines the scope of his traditionalism or the exceeding of tradition. In addition, poet among poets believed that poetry is a human activity, is force to consider its role in community awareness and at this level, dialogue with the community (people) link this poem with the tradition where traditional community affect his feeling and emotions.

However, talking about the modern poet's approach to the legacy of civilization generally requires the development of reference attached to tradition and the heritage of it, heritage is not only Arabic but also it is human heritage and tradition and the poet has a interact with this tradition of the various aspects that can be outlined to four aspects. It should be noted that the importance of these aspects are not the same, sometimes poet used them all and sometimes some of them will suffice, these aspects are:

1- National and ethnic heritage

2- Masks

3- Mirrors

4- Mythological heritage (ibid: 421)

Undoubtedly, Adonis creates new something with details and his poetry generalities, especially when speak from relationship images and significance that include of his mind, but it is the duty and responsibility of a true poet, from the era of Homer, and it is not new, Unless to restore the interpretation to link nature relationship between poetry and tradition, It is clear that poetry is the slowest human activity that stand against the tradition or deny it and is a traditional hard issues, not only in Arab literature, but also in other literature, Evolution against the language of poetry in the sense that is traditional, in fact, evolution is not against tradition, because tradition is in of his owe their periods, Evolution in the worst periods of stagnation and decline of the poem history does not deserve except when the poem to be institutionalized, or in the words of St. June press this development, is only development against the habits or the evolution of against the unnecessary language dimension, i.e. invitation to create a poetic world parallel to this world through create new expression and image relationships, evolution, despite its ambitions depend on the defeat or victory, at the same time that it will see a lot of friends, has opponents as well, one contemporary critic says: "Whenever literature closer to the word, it will see substantial and the blood in the its veins is more flowing. (Seyyedi, 2007: 43) 
When the poetry of the common cultural traditions destroyed, Poetry and irregular and continuous integration will see the words as if culture that names it is no relation and is scattered, Unimaginable explosion of words flies here and there, and poet with cowardice and malice stands against language social responsibility. In other words, the contemporary poet who believes to the changing against the tradition and cultural heritage and will not stand against evolution and natural evolution of language, But also that it deliberately wants to change through its own means, while denies any value imposed on him out. Hence, poetry was associated with the law and evolution as a poet, his poems were in a race against time, And the evolution and development of the means to transmit signals in a century poem school to another school signs of another century, but it is accelerated move of the poem, to the number of people who sing poetry. Thus, the idea (immortality) was neutralized classicism and excelling in the realm of the famous poem was temporary. This all led to believe that any value is constant, no matter where it originates and whatever its duration this category refers to stagnation and backwardness and inaction although these values are related to religion or lifestyle or way of thinking. (Ibid: 49)

After these preparations can be said that how the attitude of the Arab poetry to the tradition (on the fact)? Answering to these questions requires that we distinguish between two views: the intellectual and poetic perspective (the view that the interpretation of the poetry of it) between the two traditions, especially poetic tradition and tradition of civilization generally. However, some other thinkers or poets participated in the intellectual perspective, thinkers who have benefited from problem in the framework of their vision. Salah Abdul Saboor believes that the poet difficulty can generally ignore tradition and the great poet who is believed to be beyond the realm of tradition and to it adds something new.

Adonis in places many books chronic extension of the spoken tradition, summarized his view is "necessary to distinguish between surface and deep cultural heritage. Here surface shows thoughts, views, forms, and the depth, blasting, filling, and changing. Because of this problem the depth cannot be ignored, but also should be resolved. Therefore, new poet immersed in the depth of his heritage but at the same time, it is an independent entity, he has a beard that extends in all horizons." (Adonis, 1971: 251)

As Abu Tammam was in the past, when he was charged to the exit of poetry perpendicular (the poetic heritage) raise the Alhamaseh poems up to gathered his popular poems among ancient poems, Salah Abdul Saboor and Adonis also did, when each of them based on of his personal tastes wars - were provided deserves the survival of ancient Arab poetry. However, these poetic approach (i.e. the poetic interpretation of tradition) poets are very different. groups believe to the tradition, and assignment to it, As Tofigh Ziad as the destruction and perdition broke his back, leaned it to the "Fara rock from Hattin rocks" and the transformation of civilization tend to not ignore the past and the past are contrary to morality. (Kadkani, 2001: 52)

Adonis pauses and ponders on the negative aspect of history, so that his tone suggests that the overall refusal between him and the voices of moderation did not relational. Prose poem, "Requiem for the current day," he said of the samples, "history which is fragrant musk maidens, old and widowed women returning from pilgrimage to sweat dervishes are contaminated, in what rivers and sea be washed." (Adonis, 1971, 245)

In the past Adonis attitude connected with the origin of both refusal and progress, no question, in the context of his general attitude to the truth can get his attitude. However, contemporary myths not limited to create the character. In addition, this myth can be a village or a city, for example, Iraqi poet Al-Sayyab Badar alshaker from Jikoor village that is the his birthplace in the modern Arab poetry, has made a myth. Here we mean the application of mythical symbols in the poetry, because the myth is a language that transmits thoughts and friendly poet as well. The use of myth makes richness the artwork especially whether include contemporary view or, express the new experience.

Ernest Kasiro in their research as a prelude to the philosophy of human civilization says that there are strong links between poetry and myth, because both of them appeared in the Godheads and hero era. It is also common in the art that shows the first nations are not paid to think But also thinking 
with poetic images, based on this poet and mythmaker live in a world and both have the blessing and determination ability. These do not reflect in question, unless earlier inner life and human form to be given, another researcher in relation to poetry and myth, says: "The application of modern myth" and the result is that "we can certainly say that today all the Literature doors are closed. The only hope for a harmonious and sustained difficult to unlock the secrets of magic fascinated with the use of language is a myth. "(Al-Mousa, D.t: 89-88)

The use of myth in contemporary Arabic poetry had two aspects: one is the use of myth as the mechanical and external, and as the internal and organic.

The use of myth in a first manner appears on inconsistent contemporary experiences and seems to be work that is more decorative. and it is address the literacy and extent of information until reason for the poet's poet, This kind of use of myth appears in two forms, one of your display so that the myth is just that, in principle, is provided. In this way, the poet's task is limited to the myth of the beautiful clothes and cover new event made it to order. This type of application it is possible to experience the myth of the poet's verse of service, but the service does not experience his poem, the poet and his poetry in this way permanent dismissal is establish. Contemporary Arab poetry has many examples of this type of approach which is often belongs to the period when poets were turned to the myth. (Al-Mousa, D.t: 88-89)

Second, the use of myth refers to mythical people or events. This is the meaning and metaphorical level, and accordingly cannot move uniform mythical space to bring his poetry to be mixed. Here, thus, remove myth in a way that can be written in the spirit, from the text. There is certainly no dent in it. This type of application is somewhat likened to take a task, such as task and mythology here is just as a witness to the contemporary experience, As a result, both the poetry and myth move separate, and it seems that the myth is imposed factor to poetry and not necessary to it. Therefore, the poet uses myth to demonstrate the level of knowledge and education and to focus on more his poem that is modern until the task is to be considered. (Ibid: 92)

Khalil Hawi, a Lebanese poet in "After the Ice" poem uses the myth of Tammuz or Adonis.

Tammuz represents the life overcoming and prosperity over death and the drought. (Al-Mousa, 2002: 92-93)

This myth in the fundamental structure of poem has been influenced and shows that civilization crisis is a global issue. in the this poem the poet is mixed with myth and through the years it's recounting barrens and famine, and death, i.e. after freezing and drying the roots of the human veins, life began on Earth, one sun, mirrors and wine takes step toward collapse.

Poet to get rid of this suffering prays. At this moment, the audience by reading poetry feels in an old temple that rises from all over the smell of incense and sandalwood and from the supplication of groaning voice to be heard around stands. At this time, we would long ago to a young poet and human's childhood, shows purity and honesty and vow him in moments of need and supplication to Almighty God to us, Defenseless man who is faced with mass death and beg and supplication but does not have any weapons. That is where in angles magnificent temple, with his voice sounds and speaks from another era, the poet that is a man grappling with the death of civilization. (Hawi, 1981: 54)

Thus, we conclude that innovation is that old myth would be that in the poet poem that speak about today.

The emergence of myth in the world of Arabic literature can be considered one of the most important events and developments in contemporary Arab literature. Now, the myth of the wide variety of world literature is important.

The oldest poem that used the word myth to the lexical meaning of the poem is by poet Abdullah Ben Al-zobaari: God alien us to the mythology glory now (Al-naiemi, 1996: 21)

\section{SINDBAD MYTH IN THE POEM BY KHALIL HAWI}

In the ballad (love and peal) by Khalil Hawi poet metaphors suffering on the cross, as recorded is in the Christian tradition to speak glory of the suffering that surrounds him he fight for who loves them, in this way goes further from all the suffering and the pain to show his love in the face of the oppressors: 
(Hawi, 1972: 102-103)

(How I find rocks from a breast, hard rocks. how beat my pain and death on the ground. how honest and silence. I do not be eater; God! Return me to my land; bring me to life; to be what was. I imposed sufferings from suffering on the cross and the oppressor's celebration; however, I will meet all those who love them soon, who if they were not, were not a resurrection, passion and dream for me ...). (Hawi, 1972: 102-103)

In the ode (Seas and Dervish) by Khalil Hawi, as Sinbad the Sailor, as both mythical and poetic experiences both with each other and is parallel. Sinbad is being against peace and love movement and discovering new things invisible and Sailor (Hawi) foraging in search of certainty and difficult journey in the middle of nowhere in the life, seeks the truth. Therefore, sailor is his Sinbad, with the implications of today that have general components of traditional Sinbad itself.

Sailor ode of the Hawi descends by pain on the beach and is familiar with the contradictory experience. First Coast, Eastern Sufi vision that people prefer and in the occult adventure inactivity sink on and in the monasteries was huddled.

(After they were seasick and from dim light of the outcome of the darkness, came into the land those narrators, it was lethargy tavern, legends and sang prayers. Moreover, short palm drop shadows and whispers, damp place that kills feeling in his inflamed nerves and the memories as well as.) (Ibid: 11-12)

In this sunken dervish East Coast crept in his clergy and people continue to life in laziness and boredom and to with respect to the progress and civilization are discouraged, and prefer friary and sleep also Sailor loves rely on one of these drugs, but cannot:

(Wish ascetic of naked dervishes helped him: mentioned rings confuse them. Therefore, they left life passwords. Loops, rings around the old friary, two legs remain in the mud, but movement and everything that the dead soil out, sucks. In between its skin, the parasitic plant grows). (Ibid:13)

When Sailor sees Dervish's insistence on staying in its eastern class, left western civilization that knows it purely worthless and red and sparkle favor that immediately decays and remains useless rash. Sailor insists to discover what is in the other side. After being released from stupefaction of East and busy to courageous adventure Sinbad:

(Let me go to where I do not know where it is, I go; distant ports will not deceive me ... let me to the sea, the wind and death that spread blue and azure shrouds to tuwaa). (Ibid: 13)

Sailor in his Sindbad's trip goes to the west coast that is where does not comfort; surefire as expected, but there is coastal drowning in materialism, and extreme desires and passions. Therefore, returns disappointed and after examining all means of comfort and loses surefire, the adventure did not materialize, as he wanted and prayer in comfort stimulate in his life did not benefit. Therefore, ship then lost to the wind gives way and all the lanterns that guided him to a certainty were destroyed:

(Oh I burn in a thorny mud, with died flower, distant ports will not deceive me ... let me to the sea, the wind and death that spread blue and azure shrouds to tuwaa. Sailor, which lanterns are dead in his eyes. The light in her eyes is dead, dead, not courage and not worship ignominy safe him.) (Ibid: 19)

However, Sinbad seems stronger in poetic experience of Hawi "Sinbad in eighth trip" and more resolute in goal determination and with the more certainty in the face of obstacles that violates dominated everyone. This Sinbad is representative of the Arab growing in his struggle 50 decades, his struggle for freedom and modernity in both general and specific nature and subject (al-Kubaisi, 1978: 38)

After the sailors has in former ballad, Sinbad lost and in despair, as we see him in this experience is seen as fanning the enthusiasm to overcome recession that has hit the face of life and the essence of man. Therefore, House of lethargy and bloody Baghdad have left their friends and companions and his ship prepares to disappear into the vortex of a new sea. This new sea is the contemporary Arabian Sinbad identity. Its old values and identity confusion that density to overcome the old ideas are the ideas from famine and sterility and gloom news that the face of life, manifested in poem by Hawi, destroyed: 
(Night on the town, attract me sad desert, dust grows on my house port and I prefer to fled.) (Hawi, 1972: 277)

contemporary Sinbad with this introduction of the eighth and incentive travel authorization escape into better shape and more free from ancient intellectual heritage for our exports, Sinbad Arabic legacies in the house survived for centuries without any transformation:

(My seven trips (ended) and I do not save from God's blessing and trade, when battle with the giant and evil: the day shroud of my body was torn and the gap was revealed in the cave.) (Ibid: 228-229)

When this heritage, became a heavy burden on the Arabic house, contemporary Sinbad the need to modify its contents and prepare it to meet modern heritage. Therefore, to accelerate the transformation and reveal the flaws of its contents to discharge them at the beginning of the trip is justified. These are the contents of the intellectual, social, religious and receive them from his ship in the ocean whirlpool. However, with this action within witnessed the birth of forces that make and destroy its influence and impact on the life of logic, the logic of action taken to change the course of civilization. Therefore, dependent on the flow of ideas and behavior dictates that civilization has imposed on it. (Ashari Zayed, 2006: 36)

Original content of Sinbad that expresses is religious content.

(The house was stoic paintings decorate the walls was. Moses sledgehammer fire and human Lightning finds out that the Ten Commandments in stone inscribed with the Lord.) (Hawi, 1972: 230)

These commands even among those who consider it holy, because the torment that came to the Sodom, not respectable "pitch and brimstone and salt was in Sodom".. (Ibid: 231)

Contemporary Arab Sinbad continues to change the contents of his house and out of it is an image that reveals the contradiction between values and action, the priests who pretend to the defend its values, is a licentious and corrupt people, creative reveal what is inside:

(On another wall, is a frame: a priest at the temple fosters asp Barry and owlish that sit fertile secret on the virgins and drunkards cheers.) (Ibid: 232)

Other examples of damage to the human spread, so that the identity of all aspects of contemporary Arabic will look terrible. These samples see women unclean and s like Abul Alaye Ma'ayyeri that crawl into the back of his blindness that spent away from life and people, refraining from normal life, she finds the women ugly and dirty. (Ibid: 232) or, slave girl, who predator man oversees her by purposeless zeal forced to the murder. As in the Lorca's play, Called Blood Wedding $^{2}$ took place or foolish zeal that Dick Aljen affected by the fire to the kill his slave (Lorca and Blood Wedding in Spain and Dick Aljen sword, the day of her neck crystalline sanctum comeback, is a red river. Surprisingly, of the fear that death frozen on the lips.) (Ibid: 234)

These are all values and social heritage that Sinbad started with the release from his eighth trip to a place for new values again insists that his eighth trip to the search for them has begun.

Eighth trip of Sindbad the next step in the revolution and encouraged it to the get rid of all the things he himself is the successor to the negative legacies of the old ties that had been accumulated during seventh trips. These negative values and modern equality denies that contain them and hope that the Arab modern society rid of them, so Sinbad forces to his old home to resign in favor of his old friends, what makes this migration delicious is that the position from the blame and hypocrisy and deceit is filled with:

(Gases and toxins in the blood that flowed from the childhood I experienced the palace and used to be carved on my chest. My old friends, and I ugliness and evil, we look good. To the bad taste of the division, we sweet with a sip of Khalifa honey. (Like coffee of the Bashir Shahabi that fell poison in it). I do volubility. Such as soft pod of the sharp daggers to kill the silk snake.) (Ibid: 239)

\footnotetext{
${ }^{1}$ Refers to the torment of Sodom

${ }^{2}$ Blood bride, plays Spanish poet, Lorkan, based on the zeal that leads to the murder and in terms of the content of the story of Dick Aljen that killed his concubine to zeal incentive is consistent.
} 
In this part of the ode, the traditional experience Sinbad transferred to the experience that expression of views and includes modern implications and Arabic symbols that represent an industry that has been hit on the face of life. For example, honey Khalifa implies hypocrisy and taste sweet, but when the government is seeking relief from their enemies, to the be dipped in poison. This is what the Bashir Shahabi does, when seeking relief from their enemies, and their coffee is soaked in to the poison. (Ashari Zayed, 2006: 39)

After stepping down ancient Sinbad's place, to the record new gestures nation's birth and after a long wait, suddenly the wind of change is blowing and darkness have swept across the Arabic houses and twisted ceiling. Hawi combines Sinbad anesthesia by anesthesia of the prophets when divine revelation his.

Perhaps this anesthesia Hawi speaks it name has remained from the Islamic heritage in connection with the revelation in his memory:

(I do not claim that the angel of God has been thrown new wine and green ember in my chained and depression body, my veins the blood that he died of poison gas, refined and deleted badges and affects from my hurt). (Hawi, 1972: 246)

This anesthesia returns the Khalil to the first clean moment and converts to the child who is not ashamed from his nakedness. So that his heart will be green and the lily flower glowed in it. And during the anesthetic found certainty which is to come up into gift to the town square and knocks Arabic door of Sinbad and with his Sinbad's gifts that are the seeds of revolution brought to replace the old values at the beginning of the eighth trip throw in the ocean vortex. (Arafat Alzavy, 2005: 125)

(His steps in the square of the town, was a scaphoid that from the waves pasture in the Gulf, it takes late into the night. His steps broke the sun on crystal and shades watered its greenery and calm. The peace that except me not anyone saw.) (Hawi, 1972: 249)

If traditional Sinbad in his travels brought treasures, jewelry and beautiful stories and calming, modern Sinbad in his eighth trip, tidings "Eye certainty Dream and touching". (Ibid: 265)

The sense that the Arab nation is ready to true birth and difficult revolution that stands against the wind and snow.

(It was not that I respect the sun, if i did not see that you wash the morning in the Nile, the Jordan and the Euphrates from guilt, and anything is hill that shines in the sun. However, alligators are gone from our land.) (Ibid: 266)

In this part of the ode, the myth of Sinbad some ethnic sorrows affected depth of the Hawi, is tired and speaks the language of modern Sinbad that is not carry traditional features. Sinbad have different sorrows, ambitions, and dreams of for itself.

(Like a poet that has a tidings on his face returned to you, everything that says is based on the nature of what is in the womb of the season, feels he sees them in seasons before his birth). (Ibid: 271)

Other tourists from distant lands Magus is in the Bible, those who came from the east to Quds, following the star. They believe the star pointed out to the birth of Jesus. The incident happened in the era of the Roman Hyrodos. They followed the star before them, came to the place where the child was with his mother, the star stopped and they fell prostrate to the ground. (Bible, Matthew, second Sihah 4)

Khalil Hawi uses this myth in the "Magus in Europe" ode knows magus equal to the poet and all seekers of certainty in this world; those assume that their lost is in the new west civilization. If Magus in the Gospel found their lost and calmly returned, this time the character Magus as a Khalil Hawi has been manifested, except with the fall have not returned from their journey. Suddenly, they are faced with ugly and dark materialistic civilization that is soulless and principles of ethics, it has gone and so not finds the true Christ, and priests had hidden him and the star that they had followed, has been sunset. (Arafat Alzavy, 2005: 135)

(Adventurer star brought us. In Paris ... test thought monasteries. We released thought in celebration of passengers (Masquerade). Moreover, lust priests in Rome, the stars in the sky and it wiped out in the Ember of lamps. Then we lost it in London and we lost in coal smog in architecture of business.) (Hawi, 1972: 109) 
Summary experience of release seekers at this time, is that the Western civilization, even on the eve of the birthday have not respect for spiritual values, because people behavior is away from moral, so that people tend to pleasures of the flesh unlawful under the slogan of freedom and East spiritual values are considered as a disadvantage and ridiculous it:

(With red lights were directed toward the door, which this word engraved on it: an earth paradise! Here snake neither for misleading nor for religion to stoning. Flower is thorn less here. Here, the nudity is same innocence. These figures borrowed from evil chameleon skin been stripped of on your own.) (Ibid: 112)

However, the East from the perspective of modern tourist is not better than the West, the East suffering from the fall and faces duality and intellectual dependence. This is one of the reasons that a modern Magus had been forced to find freedom to the West:

(We neither taken of our faces nor put on our faces. We are from Beirut and the tragedy is that we came with faces and wisdoms loaned to the world. Thought in extramarital market occurs and then all of life is to reform virginity.) (Ibid: 113)

When the Eastern were not found freedom in their homeland due to the weakness and dependence, they have been surrendered to the achievements of Western civilization and thus more slinked in lusts and corruption. Khalil Hawi in this space of crisis in Arabic modern human in dealing with civilizations west, particularly the intelligentsia says:

(We like to humble knee alchemy and wizard that at cemetery night, paradise was dark.) (Ibid: 115)

If the Magi in the Gospel by achieving certain conscience slept, the Magi followed by their modern materialist West, were more confused because of their meeting with Christ that Khalil has saved him on social and intellectual aspects into account, have been disappointing:

(O God of fatigues, disorientations, $\mathrm{O}$ God, flees battle with the sun, and a certain fear hidden in the cave in caves in the underworld, the land of civilization.) (ibid: 115)

Hawi often has chosen the myth for awakening of the Arab nation and their resistance against the enemy. He speaks the language of legends with his contemporaries and considers this format appropriate means to express their ideas of modernist. Among contemporary poets, he spent most of the myth of Sinbad. In the words of the poet, Sinbad has become a symbol of that is understandable to the public (Ashari Zayed, 2006: 61).

Hawi's Sinbad, is a mythical person, with the adventurous spirit. He always shows a lot of enthusiasm coming out of the lethargy. Therefore, he continued to travel and immersed in the fresh sea. Hawi in the "Sindbad faces," ode draws the beaming faces of curious sailors at the start of the journey, but the long journey to get hurt, happiness and sadness from him, and fatigue is replaced. In fact, Sinbad in this poem, the poet is that pre-occupation of Arabic lands, has been a fresh face, but accidents, tragedies and unjust aggressors seated other roles on his face. (Aldaya, 1990: 251) Poet in this poem, like Sinbad of Thousand and One Nights Legends that tried to seventh travels leaves behind multiple trips and in each trip has a new face and other form replace instead of his past face, and finally the face that was heated at the beginning of the way, due to the tragedy, loses its freshness:

(I know that I have wheaten and fresh face, and I did what my face is not the face that age injury covered the ignorance of the system, such as obsolete and has been changed my face, like the face of someone who is on the way there has been confusion.) (Hawi, 1979: 224)

However, Hawi's Sinbad, contrast to the Syab's Sinbad, despite many failures, do not lose hope. He is in dream of child who despite his green ways of living and blessed future is built:

(... Be sure will soon be lush, tomorrow in the childhood, is green, that his life is you and I, our blood, returns in his blood, fertile and exuberant.) (Ibid: 224)

In The poem by Hawi, his personal experience and surrounding reality is linked with each other and best reason is "Sinbad in eighth trip" ode. (al-Musa, Dt: 35) between 1956 and 1958 he sang the ode, when the Arab world, waiting natal to improve their miserable condition.

Sinbad's eighth trip, a new character is being able to change the reality. After the house (password of ancient civilization) destroyed and put an end to corruption, new house (password of new civilization) is founded. 
Khalil For the heterogeneities that exist between Arab civilization with the West do not remain silent, to face his Sinbad, given the socio-cultural color. If Sinbad of other poets follows other matters, his Sinbad wants a new civilization. Hence, by space and deal with of Hawi to the legendary of Sinbad we conclude that this myth in the poetry, depend on his personal experiences and is an image of the poet that has a profound philosophical orientation. (Hawi, 1981: 34)

He to achieve new ideas and reach to new civilization, risk everything and the legendary of thousand and One Nights Sinbad, deals adventure and accepts any danger. Hawi in "The Eighth trip of Sinbad" when he links with Sinbad, in fact, takes the scenes of personal and social pains and emphasizes the need to sacrifice to get rid of it. Therefore, the fact that Sinbad is out of it, is a painful reality. $\mathrm{He}$ is under backwardness, ignorance, disease of social, education, and its paradoxes. (Rajai, 2002: 43), but it is important that Hawi's Sinbad on this trip, leaves all difficulties:

(I left home, I leave it up to be the old shelter for old friends, and day and night, I clean my home from echoes of their silhouette, and my chain, my sword, and I lived with the expectation.) (Hawi, 1972: 267)

In use of this myth, Hawi success to manage between itself, theme, whole, and part, communicate, has melt in a total perfect and thereby to achieve organic unity and gain new experience and a two-dimensional, the personal and legacy aspect. (Abbas, 1992: 130) Sinbad in this poetic experience of Hawi (Sinbad in eighth trip) is capable in determining the purpose and in the face of obstacles, emerges with more certainty. His Sinbad is a password of Arabic nation that wants to leave lags behind, to be born again and has own the gospel of the birth of a new civilization in which the most influential people in the universe is made. Hawi's Sinbad task is unraveling the human tragedies and catastrophic hardships in his society in which man is oppressed brutally. Sinbad mission is condemning the catastrophic situation, something that seems to be done with Hawi's Sinbad and Syab's Sinbad could not do it. In the second part of the poem "Faces of Sinbad" where the modern Sinbad journey begins in the train, says:

(First night was bitter and his first day in a strange land bitter was, successive nights, it was bitter, He is a long time that fortitude on the thirst, the hunger and the lust, bitter, self-absorbed, review past memories, he clear dust of the journey with means that has been filled a suitcase.) (Hawi, 1972: 225)

Hawi's Sinbad believes that the expiry date of heritage is finished; hence, he is intended to change it proportional to the time. Therefore reveals flaws and such within itself will see the birth of forces that change by his effectiveness, creates the first change in religion, and reveals conflict between values and action. He portrays a priest who pretends to defend of values:

(On another wall, is a frame, and the priests in the temple of Baal, which snakes breeding and fertility owl that password in Maidens breaks and drunkards who are cheering.) (Ibid: 259)

The next step in this journey, trying to get rid of the negative legacies of the old Sinbad during his seven voyages has been familiar with it. His Sinbad will destroy the old house, registers new signs of the birth.

Hawi's Sinbad in his eighth trip heralds to preparedness of Arabic community for uprising and revolution. He knows the sun is the password of freedom and the dignity it and realized that Arab world has modern their heritage, and with their alliance, push back their enemies that call as "crocodile":

(It was not that I respect the sun, if i did not see that you wash the morning in the Nile, the Jordan and the Euphrates from guilt, and anything is hill that shines in the sun, fragrant shadow and clean lake, However, alligators are gone from our land, while our sea roared and was hidden within them.) (Ibid: 294)

New Sinbad (eighth trip of Sinbad) that left behind seventh trips and this eighth trip, this time is his story. He in seventh trips had lost all their capital, but in eighth trip, achieved evangelistic.

Hope as the sun was shining in his eyes. This hope was the dream of a new world. (Kadkani, 2001: 152) he described the latest trip by good news: 
(Destroying my capital and business, but I came to you in the poetry of his mouth has a good news, says what it says, by nature that everything is in the womb of season, feels, and be born before the season, sees it.) (Hawi, 1972: 299)

Khalil is in modern art of Sinbad, Sinbad in "Sindbad faces" and "Sindbad in eighth trip" new myth, the myth of modern man, and struggles with the realities and efforts to get rid of the huge experience in area and sent to the broader concerns of Sinbad a proposition nation and civilization, which suffers from underdevelopment.

\section{CONCLUSION}

- The most obvious function of mythology is explanation of and cultural natural facts

- Many myths explain the rituals and traditions and we can say that the myth valued ritual celebration and credibility and gives value to life.

- The emergence of the field of Arabic poets in the land fertile minds rebel myth, a myth in the story they like precious stones that help the mind could process every time a new body to shave it.

- Phoenix is the symbol of fire in contemporary poetry is most used among mythology so that even using the technique of contentment; consider other mythology of the flame of Phoenix fire.

- Largest concern of Khalil Hawi is Arabic community and land that an unfriendly faces them and as a camel driver constantly try to push and driven them away society from ignorance and backwardness and imagine a larger and brighter horizon devoted to them. And to escape reality Arabic world to the world of myths, trying to realize their aspirations and the most important pretexts them in this way from the myth of the phoenix is the symbol of fire.

- Modern Arabic poetry realize for poetry's aesthetic benefits of using a self-made and have refused direct address therefore, their poetry has been dramatic and convincing and could become more daring and deliberation and concise expression of existential concerns common to modern times change.

-Modern poets in using some of the traditional elements clearly are common; this share due to the fame of those elements is full of significance.

-It is noteworthy that traditional domain of poetry had more attention by modern poets and sometimes have been successful in ensuring their poetry so that guarantees was part of their texts and sometimes have not been success and was a guarantee of additional burden on texts.

\section{References}

[1] Abbas, E. Who stole the fire, Beirut: Institute of Arabic Studies and Publishing, 1980.

[2] Adonis, A. A. S. Poetic works full, Beirut: Dar Al-Aodeh, 1971.

[3] Al Daya, F. Aesthetic style, Beirut: contemporary thought, 1990.

[4] Al-musa, E. Of rain song to rose psalms, Tehran: Sokhan publications, 2002.

[5] Almusa, Kh. A myth in Arabic contemporary poetry, translated by: M. Bydaj, Poetry Magazine, No. 28 (D.t), pp 82-97.

[6] Al-Naiemi, A. I. Myth in Arabic poetry before Islam, compelling: Sina to publish, 1996.

[7] Al-kubaisi, T. The Arab heritage as a source in the theory of knowledge and creativity in the modern Arab poetry, Baghdad: Ministry of Culture and Arts, 1978.

[8] Arafat Alzavy, A. the function of tradition in Arabic contemporary poetry, translated by: Hossein Seyyedi, Mashhad: Mashhad University publications, 2005.

[9] Ashari Zayed, A. Call Martyrs heritage in contemporary Arab poetry, Cairo: Dar Algharib, 2006.

[10] Bahar, M. Query a number of Iranian Culture, Tehran: Fekre Rooz publications the Cultural Revolution, 1994. 
[11] Eliade, M. myth landscapes, translated by J.sattari, Tehran, Toos, 1983.

[12] Hawi, E. Khalil Motran pioneering modernist poets (the forefront of modern poets) Beirut, 1981.

[13] Hawi, Kh. Full poems poetic activities, section 2. Beirut: Dar- Aloadeh, 1972.

[14] Rajai, N. Freedom myths: psychological analysis of myth in Arabic contemporary poetry, Mashhad: Ferdowsi University of Mashhad, 2002.

[15] Salimi, A. comparative study of Sinbad myth in Badar Shaker Al-Sayyab and Khalil Hawi poetry, Arabic Language and Literature magazine, issue 3, No.4 (2011), pp 22-34.

[16] Sattari, J. Myth and Secret (Researches), Tehran: Soroush, 1995.

[17] Seyyedi, S.H. Symbolism in the poetry of Adonis, Isfahan University Faculty of Foreign Languages Quarterly, No.1 (2007), pp 38-52.

[18] Shafie Kadkani, M. R. Contemporary Arab poetry, Tehran: Sokhan publications, 2001. 